\title{
PHAGOCYTIC ACTIVITY OF LEUKOCYTES IN SHEEP AND GOATS
}

\author{
V. BENDA and J. HOŠPES
}

Institute of Animal Physiology and Genetics, Czechoslovak Academy of Sciences, 10400 Prague

Received May 16, 1990

\begin{abstract}
Benda V., J. Hošpes: Phagocytic Activity of Leukocytes in Sheep and Goats. Acta vet. Brno, 60, 1991: 149-152.

Phagocytic activity (PA) of polymorphonuclear and mononuclear blood leukocytes from sheep and goats was measured using two different types of inert particles ingestion. The percentage of phagocytizing cells reached up to $67.83 \pm 5.58 \%$ in granulocytes and $3.74 \pm 0.43 \%$ in monocytes as determined by 2-hydroxyethylmethacrylate particles (MSHP) in sheep and goats. The PA determined by means of $\mathrm{CdCO}_{3}$ microcrystals saturated with human serum albumin (Cd-HSA) was 30-50\% lover then the MSHP values, particularly in sheep.
\end{abstract}

Phagocytic ingestion, small ruminants, inert particles

Phagocytosis is an important mechanism of nonspecific immunity in which antigen is engulfed, hydrolysed, fragmented and then presented to other immune cells for initiation of the specific immune response. In the blood, polymorphonuclear (PMN) and mononuclear leukocytes act as "professional" phagocytes. Defects of phagocytosis, inborn or acquired, belong to important factors disposing the animal mainly to infectious diseases (Rotrosen and Gallin 1987). The follow - up of phagocytic activity (PA) consisting in percentual determination of phagocytizing and nonphagocytizing leukocytes - neutrophils, monocytes (MN) and exceptionally also eosinophils - yields important information on the immunity and belongs to the basic methods in clinical immunology. Due to their simplicity the tests evaluating one of the steps in phagocytosis - ingestion (i. e. absorption of an alien particle by the phagocyte) - became widely used in both human and veterinary medicine. As standards various particles of natural (microorganisms) or synthetic (Latex particles) origin are employed (Absolom 1986).

The study reported here was designed to compare two methods of the phagocytosis evaluation in healthy sheep and goats.

\section{Materials and Methods}

Experimental animals consisted of 17 female goats (Bohemian White) 6 months to 5 years old and a group of 22 female sheep (Mutton Merino) of the same age range. These animals came from the own Institute's breed and were kept ( $2-5$ animals per house) on deep litter and fed in conventional manner.

The blood was sampled into silicon-coated test tubes and was mixed with heparin (5 I.U. per $\mathrm{ml}$ ). Total leukocyte count was determined after adding Türk's s solution in Bürker's hemacytometer. For determination of leukogram the blood smears were panoptically stained.

The phagocytic activities of PMN and $M N$ were examined by two different methods in whole blood. The samples were treated within $30 \mathrm{~min}$ after sampling using silicon-treated glass. The staining of smears was made using Pappenheim's standart panoptic method. PA tests were performed by the evaluation of at least 200 leukocytes capable of phagocytosis. The PA value is expressed as the percentage of cells with phagocytized particles from to the total number of leukocytes without lymphocytes. The following methods of the PA determination were used: 
- MSHP using 2-hydroxyethylmethacrylate synthetic hydrophilic particles (Větvička et al. 1982). In brief, $0.05 \mathrm{ml}$ MSHP (Institute for Research, Production and Application of Radioisotopes, Prague, Czechoslovakia) diluted with PBS to approximate concentration of $5 \times 10^{8}$ particles $/ \mathrm{ml}$ were mixed in a test tube with $0.1 \mathrm{ml}$ whole blood. After the incubation for $60 \mathrm{~min}$ at $37^{\circ} \mathrm{C}$ with occasional shaking blood smears were prepared. The cells containing 3 or more absorbed particles were considered as phagocytizing.

- Cd-HSA using $\mathrm{CdCO}_{3}$ crystals saturated with human serum albumin ( $\mathrm{Palisa}$ et al. 1978) kindly provided by Prof. V. Palisa, Medical Faculty, Charles University, Plzeň, Czechoslovakia. Microcrystal suspension of $0.6 \mathrm{ml}$ was centrifuged $5 \mathrm{~min}$ at $1000 \times \mathrm{g}$ and the supernatant was discarded. To the pellet $1 \mathrm{ml}$ blood was added and the mixture was incubated $30 \mathrm{~min}$ at $37^{\circ} \mathrm{C}$. The reaction was stopped by adding $5 \mathrm{ml}$ of $5 \%$ aquaeous chelaton III solution (Lachema, Brno, Czechoslovakia) which dissolved nonphagocytized crystals, for $30 \mathrm{~min}$ at room temperature with occasional shaking. The blood smears were prepared from the pellet after preceding centrifugation at $300 \times \mathrm{g}$ for $5 \mathrm{~min}$. The phagocyte with already 1 or more crystals was considered active.

\section{Results}

The actual PA evaluation was precedent in all animals by the determination of total and differential leukocyte counts. Mean values of the individual groups are presented in Tab. 1. Using the MSHP method especially the neutrophil granulocytes showed considerable PA in comparison with quite negligible activity of eosinophils. PA of both cell types (under common designation PMN) are presented in Tab. 2. In MN, the FA was generally low. Intensively blue-violet stained MSHP particles are located in the cytoplasm or extracellularly, their intraphagocyte counts varying from 1 to 25 particles. If Cd-HSA particles were used for PA determination, they were phagocytized in goats exclusively by neurophils and $M N$. In three sheep, eosinophils were active, yet PA of this cell type did not exceed 0.05 . Cd-HSA microcrystals were visible only in the cytoplasm as bright, shining, unstainable granules. In this test, PA manifested considerable individual differences. Average results for each species are given in Tab. 2.

\section{Discussion}

Contrary to the group of goats which showed normal total and differential (leukogram) leukocyte counts, findings in sheep were characterized by values at the lower limit of the norm accompanied by moderate eosinophilia. Even if in many monographs the normal leukogram data differ, which is probably caused by breed character, unfavourable effects of latent parasite invasion in our sheep cannot be excluded. Focusing attention on the main aim of this study, evaluation of PA by two different methods, it was found, that the values obtained in both species

Table 1

Total and differential leukocyte counts in sheep and goats

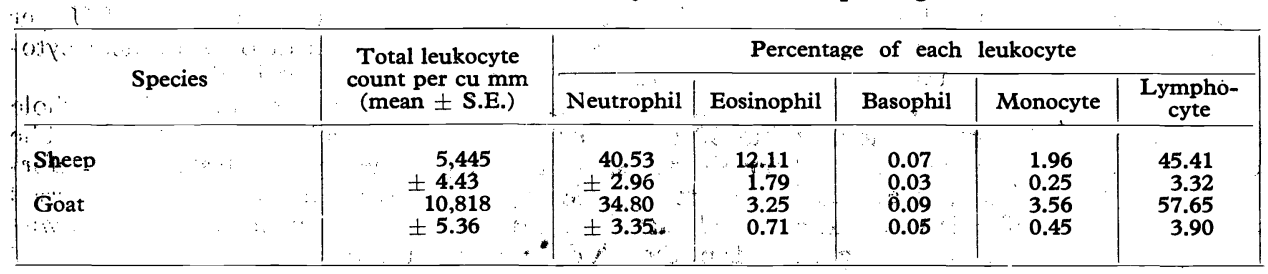


Table 2

Phagocytic activity of granulocytes (PMN) and monocytes (MN) in sheep and goats evaluated by different methods

\begin{tabular}{|l|c|c|c|}
\hline \multirow{2}{*}{ Method } & \multirow{2}{*}{ Species } & \multicolumn{2}{|c|}{ \% of active phagocytes (mean \pm S.E.) } \\
\cline { 3 - 4 } & & PMN & MN \\
\hline \multirow{2}{*}{ MSHPa } & Sheep & 64.56 & 3.20 \\
& Goat & \pm 2.21 & \pm 0.33 \\
Cd-HSAb & Sheep & \pm 7.83 & 3.74 \\
& Goat & 28.87 & \pm .43 \\
& & \pm 4.06 & 2.26 \\
& & \pm 6.30 & 1.89 \\
& & \pm 3.69 & \pm 0.30 \\
\hline
\end{tabular}

a - 2-hydroxyethylmethacrylate particles

b - $\mathrm{CdCO}_{3}$ microcrystals saturated with human serum albumin

using Cd-HSA were about one-third lower as compared with the MSHP method. Neverthelless, if we recall the basic difference of both tests consisting in the possibility to all extracellutary localized Cd-HSA particles, the finding was not surprising. Due to lack of data in other animal species we had to use for comparison the PA values found in healthy humans. They vary using Cd-HSA method between $30-40 \%$ for PMN and 5-10\% for $\mathrm{MN}$ (Palisa et al. 1978). PA values found in our experiments were most pronounced in PMN and correlate with the upper (goats) or lower (sheep) limit of this norm. The data obtained by the MSHP method can be compared with similar results in calves (Toman and Pšikal, 1985; Paulik et al. 1987). The lower PA of MN seen in our animals can be explained, beside the specifities in cell separation, mainly by different evaluation based on the number of ingested MSHP particles. Contrary to the studies metioned above, in our experiments only the cell containing as least 3 phagocytized particles was considered active. If the lower PA of the sheep PMN and MN in the comparison with goats as determined by both methods is connected with species character of deviations in the differential leukocyte counts discussed earlier, cannot be decided finally. However, the PA as measured by both methods was also influenced by the opsonizing activity of plasma components (immunoglobulins, complement).

In conclusion, comparing the two methods of PA evaluation from the point of view accuracy and suitability, the MSHP method seems more suitable despite of the potential hazard of higher values. The procedure using Cd-HSA particles is considered more precise, yet its routine application in ruminants is limited by the difficult legibility of the test results in full blood smears. Nevertheless, it can be employed as standard method for comparison of various tests measuring phagocytic ingestion as an important mechanism of nonspecific immunity.

\section{Fagocytární aktivita leukocytů u ovcí a koz}

Fagocytární aktivita (PA) polymorfonukleárních a mononukleárních leukocytů periferní krve ovcí a koz byla stanovena ingescí odlišných typů inertních částic. Podíl fagocytujících buněk dosáhl u granulocytů $67,83 \pm 5,58 \%$ a u monocytů $3,74 \pm 0,43 \%$ při použití 2-hydroxymethylmethakrylátových částic (MSHP). Hodnoty $\mathrm{PA}$ získané aplikací mikrokrystalủ $\mathrm{CdCO}_{3}$ nasycených lidským sérovým albuminem byly ve srovnání $\mathrm{s}$ předchozím testem o $30-50 \%$ nižši zejména u ovcí. 


\section{Фагоцитарная активность пөйкоцитов овец и коз}

Фагоцитарную активность (РА) полиморфонуклеарных и мононуклеарных лейкоцитов периферийной крови овец и коз определяли поглощением различных типов инертных частиц. Доля фагоцитирующих клеток у гранулоцитов достигла $67,83 \pm 5,58 \%$, у моноцитов $-3,74 \pm$ $\pm 0,43 \%$ при применении 2-оксиметилметакрилатных частиц (MSHP). Величины PA, полученные применением микрокристаллов $\mathrm{CdCO}_{3}$, насыщенных человеческим сывороточным альбумином были по сравнению с предшествующим на 30-50\% ниже, в особенности у овец.

\section{References}

ABSOLOM, D. M.: Basic methods for the study of phagocytosis. In: G. Di Sabato and J. Everse (Editors), Immunochemical Techniques. Methods in Enzymology, 132, 1986: 95-180

PALISA, V.: Method for evaluation of phagocytic activity in vitro. (In Czech) Imunologický zpravodaj, 9, 1978: $42-44$

PAULfK, S.-SLANINA, L.-DUBAJ, J.-SKOTNICKÝ, J.-GEDEON, V.: Phagocytosis of calves and its changes after an experimental treatment. (In Slovak) Vet. Med. (Praha), 32, 1987: 93-104

ROTROSEN, D.-GALLIN, J. I.: Disorders of phagocyte function. Ann. Rev. Immunol., 5, 1987: $127-150$

TOMAN, M.-PSfKRAL, I.: Phagocytic activity of blood leukocytes in calves from birth to the age of three monts. (In Czech) Vet. Med. (Praha), 30, 1985: 401-408

VĚTVIČKA, V.-FORNƯSEK, L.-KOPEČEK, J. - KAMfNKOVA, J. - KAŠPÁREK, L.VRÁNOVA, M.: Phagocytosis of human blood leukocytes: A simple micromethod. Immunology Letters, 5, 1982: 97-100 